\title{
IMPLEMENTING CRITICAL READING FOR READING COMPETENCE
}

\author{
Afief fakhruddin \\ English Language Education Study Program, Universitas Majalengka \\ afieffakhruddin@unma.ac.id
}

\begin{abstract}
The aim of this study was to investigates the impact of critical reading strategies on students' reading competence. The participants of this research were semester three students of English education. The sample of this research was twenty three students. This research used test and observation to determine their level of reading competence during the learning. The research showed that this Strategy enhanced students' reading competence. The students' means score in cycle two test was (80.95). the result was much better than cycle one (70.94). Based on the result above it can be concluded that critical reading could enhance sudents reading competence.
\end{abstract}

\section{Key words: critical reading, reading competence.}

\section{Introduction}

Reading is a tool of communication in written language through the text form. It is the most efficient way to gain information about many aspects of life, including science and tecnology. By reading, people can absorb a number of information (Ismail, Syahruza and Basuki, 2017:125). Based on the theory above, it can be explained that reading activity is important to enhance someone ability in learning somthing. There are a lot of strategy in teaching and learning reading. Students feel lack of information while they are reading an English text. English is not first language for all students, so they need time to practice every skill in English. According to Akin, Koray and Tavukcu (2015, p.2445) assert that an individual's ability to keep what he has read in his mind for a long time can only be possible with critical reading which requires a process of active communication where comments and evaluation on the text are conducted.

Every English words have meanings. Futhermore reading need students comprehension in finding a meaning and message. This is in line with Similarly Khabiri and Pakzad (2012) mention that literature reading courses often make students find out just about literal meaning and form-based items while focusing on the surface reading. They maintain that it takes away students creativity and talents and just inhibit thinking and critical reading. Students sometime feel difficult in pronuncing a vocabulary, because they have not practice a lot. This phenomenon influence in students ability in give critical analysis. Critical reading is basically a reading process which involves critical thinking. Thus, to define critical reading necessitates an understanding of the meanings of reading and critical thinking. Recent theories view reading stated that it is not just extracting meaning from a text but a process of 
connecting information in the text with the knowledge the reader brings to the act of reading, (Perdede, 2007:3).

Reading is an active process that requires a great deal of practice and skill (Moreillon, 2009). Based on the explanation above, it can be explained that reading activity needs more concentration in identifying the text, because there are a lot of form of words. If the words is in different form, the meaning will change too. Reading is a mental process. There are many meanings of reading. Reading is making meaning from print and from visual information. But reading is not simple. Reading is an active process that requires a great deal of practice and skill (Moreillon, 2009). Based on theory above, it can be explained that reading activity make students should read whole sentence. The activity makes students to do great effort to develop reading skill.in the learning process, students are not motivated in reading the text, so they will not get information and meaning from the text.

Urquhart (1998: 14) as cited in Parmawati and Yugafiati (2017) states that reading means dealing with language message in written or printed form. Reading is an activity that provides a lot of insight and knowledge. Based on the theory above, it can be explained that transferring knowledege can happen during reading activity. Students will know to identify and select information from the text. There is a beneficial for students in reading the text. The students have more knowledge and it can help them to memorize every single words.

Having critical reading skills help to deepen a student's comprehension of a text, resulting in a positive reading experience, Rosdiana (2015). Based on theory above, it can be explained that students reading skill will improve during the activity. The students will be easy to find out the main idea and supporting details fromt the text.

critical reading is important to be intergrated to help students in understant the text and to develop some reading minor skills, especially for EFL students who need to develop decoding and vocabulary skills in order to read better (Zhang, 2007). From the theory above it can be explained that memorizing vocabuary is still become difficult thing for second language learner. lack of vocabulary will give impact to students skill in learning all English skill especially spoken and written form. The students will not be able to pronunce the vocabulary and the students should practice to enhance their citical reading skill.

Critical reading has its own characteristics which make it differetnt from general reading. (Kurland 2010) remarks that critical reading means analysing. He further states that throught discussion, the readers can identify element pattern such as informations, and language usage. Analysing, interpreting, and evaluating are some activities which can be done in critical reading (Kurland, 2010).

Based on theory above, it can be explained that citical reading can be practiced by students. It is depend on students will. If the students do more practice in identifying the text, their critical reading skill will improve.

Vallee (2011), proposes 4 main steps of critical reading which need at least three times. The steps are as follow: a) Previewing: by skimming and predicting, b) Annotating and analyzing: by making note and analyzing the main idea supporting idea, 
c) Reviewing: re-reading by accounting the note and unfamiliar words, d) Respoding: by summarizing or discussing with others. These activities present the main ideas of the text briefly by writing or retelling it by readers own words (Fadhillah, 2017:95). Based on the theory above, it can be explained that reader have to know the requirements in critical reading. In the begining, they have to select reading strategy to make reading activity more efficient. Next steps is simplify the text with their own words. By following this steps, the reader will enhance their ability in comprehence the text and they will be easy to retelling the text.

According to Perdede (2010:5), As a process of questioning and evaluating printed material by involving one's ability to think critically and to react intelligently to the writer's ideas, critical reading is carried out by asking oneself certain questions as he is reading in order to interpret the author's ideas critically. From theory above, it can be explained that interprating the text will increasing students comprehension to the text. Students will be able to interpret and give their own perception, and it's become their writing habitual.

This characteristics have been mapped into three cognitive 'hierarchical stages' of the surface code (literal reading), the text base (basic inference by interconnecting the text)), and the situational model (making inferences through connecting the text and background knowledge) (Wang \& Gierl, 2011). From the theory above, it can be explained that connecting between text have meaning. Getting a meaning in reading comprehension need skill, because it is not only understanding the text but also finding a message. The students should do more practice and exercises to develop their skills in reading.

Based on the explanation above, the author interested in conducting a research about reading competence and formulated a research question how is students improvement learning reading competence through this strategy. text through transition action detail.

\section{Research Methodology}

\section{A. Research Design}

According to Creswell (2002) noted that qualitative research is the approach to data collection, analysis, and report writing differing from the quantitative approaches. The research was Classroom Action research. The author selected this analysis to improve students competence and implement reading strategy to be higher. According to Mertler (2009:12), Action research is about developing the professional disposition of teachers and the teaching profession. From the theory above, it can be explained that class room action research helps lecturer in teaching material. The lecturer will know evry single processes in their students, because in this reasearch action research defided into some steps such as planning, action, observation, and reflction. In the end of cycle I, the obstacles that were faced by the students in cycle I was reflcted and improved in cycle II. The population of this resaerch was semester three students of English department. The sample was twenty three students. 


\section{Technique of collecting the Data}

In this part, the researcher explained about instrument and how the data calculated.

1. Test

In this research, the researcher used reading tests to measure students' ability in understanding the text. Johnson and Larry (2012:197) test is used to measure attitudes, personality, self-perceptions, aptitude, and performance of research participants.

\section{Observation}

According to Narbuko \& Ahmadi (2010:70), Observation was the tool to collect data which is done by observing and noting down systematically the phenomenon that is inquired. Based on the theory above, it can be explained that the beneficial of observation sheet was make record about student activities during teaching learning process especially when the critical reading applied in the teaching learning process.

\section{FINDINGS AND DISCUSSION}

In this part, the author explained and analyze the data after the author was implementing critical reading in the classroom.

\section{Findings}

The quantitative data were taken from the results of students exercise. The test and exercise were relevant to the reading topic in each cycles. The author implemented two cycles consisted six meeting during the research and the author cheked the last of every cycle. During the research the author conducted this strategy for 2 cycles, the students reading competence improved, particularly in finding main idea and understanding the meaning.

\section{Students' average score}

The result of the analyzing data explained that there was enhancement of students' reading competence, trought critical reading. The result can be seen from average score of the students. In the post-test in cycle II is 80.95 higher than the mean score in cycle I was 70.94. During implementing critical reading, the researcher used observation sheet, this instrument helped the researcher to take notes every students activity and push them to be more creative and focus during implementing this strategy. Based on the observation result, the author found that students interested in Critical reading activities. It happened because the students know the beneficial of this reading strategy. The students had known how to immplement this reading strategy, so, they were so easy to identify the meaning within the text.

Based on findings above, it was found that the strategy of critical reading enhance students interest and competence in reading text. It can be seen from the mean score of cycle two. 


\section{CONCLUSSIONS}

Based on findings and discussion above, it can be concluded that this reading strategy helped students to enhance their ability in reading competence. It can be seen from the average score from students test. Based on the result of cycle two was higher than cycle one. Most of the students feel easy after learning reading this reading strategy. The students are able to find out main idea and message during pharaprase the text

\section{References}

Akin, F., Koray, O., \& Tavukcu, K. (2015). How effective is critical reading in the understanding of scientific texts. Procedia - Social and Behavioral, 174, 2444- 2451.

Creswell, J. W., \& Plano Clark, V. L. (2011). Designing and conducting mixed methods research (2nd ed.).

Fadhillah, Ajeng. M. 2017. Ambedding Crritical Thinking Through Critical Reading Teaching Narative Text in Junior High School. journal of English and Education.

Johnson, B. \& Larry, C. (2012). Educational research: Quantitative, qualitative and mixapproaches $\left(4^{\text {th }}\right.$ ed.).ThousandOaks,C SAGE Publications,Inc.

Khabiri, M., \& Pakzad, M. (2012). The effect of teaching critical reading strategies on EFL learners' vocabulary retention. The Journal of Teaching Language Skills (JTLS). 4(1), 73-106.

Kurland, Daniel. J. 2000. Critical Thinking vs Critical Reading. www.crticalreading.com.pdf

Mertler, Craig A. (2009). Action research: Teachers as researchers in the classroom.

Thousand Oaks, CA: SAGE Publications, Inc.

Moreillon, J. (2009). Collaborative Strategies For Teaching Reading Comprehension: Maximizing Your Impact. Chicago: American Library Association.

Parmawati, A., \& Yugafiati, R. (2017). Using Authentic Material To Improve Students'reading Interest (A Classroom Action Research In The Second Semester Students Of Stkip Siliwangi Bandung). Eltin Journal, Journal Of English Language Teaching In Indonesia, $5(1), 1-8$.

Perdede, P. 2007. Developing Critical Reading in EFL Classroom. p.3. 32Rosdiana. 2015. An Overview of Critical Reading Strategies to Efl Students. Getsempena English Education Journal.

Valle, Manuel. 2011. Teaching Critical Readin.

Zhang, L., \& Seepho, S. (2013). Metacognitive Strategy Use and Academic Reading Achievement: Insights from a Chinese Context. Electronic Journal of Foreign Language Teaching, 10(1), 54-69. 
